\title{
Studi Literatur Tentang Pengaruh Demand Bus Antar Kota Terhadap Kualitas Udara di Area Terminal
}

\author{
Fithri Estikhamah ${ }^{1}$, Anna Rumintang ${ }^{2}$ \\ ${ }^{1,2}$ Program Studi Teknik Sipil, Fakultas Teknik, Universitas Pembangunan Nasional "Veteran” Jawa \\ Timur \\ E-mail : fithri.ts@upnjatim.ac.id ; anna.ts@upnjatim.ac.id
}

\begin{abstract}
Economic and non-economic development are things that require the role of transportation. Terminal is one of the services provided by the private sector and government to meet the increasing needs of public transportation. Which gives the biggest contribution in terms of air pollution is the terminal, because it is the center of all activities that use transportation services both terminal managers, traders, and service users. Air pollution comes from industrial chimney fumes and exhaust gases from motor vehicles. The use of motorized vehicles has a negative impact on the environment, especially the exhaust gases from the combustion of fuel that is not decomposed or burned completely. The biggest contributor to pollution is the substance, the substance in question is a sulfur oxide (SOx). Air pollution has negatively linked human health in general. In this case the impact on food traders around the terminal area was particularly affected. These traders are exposed to air pollution every day. This writing aims to determine the impact of air pollution on the health of traders.
\end{abstract}

Keywords: air pollution, sulfur oxide (SOX), transportation

\begin{abstract}
Abstrak
Pembangunan ekonomis dan non ekonomis merupakan hal-hal yang membutuhkan peran transportasi. Terminal merupakan salah satu jasa layanan yang disediakan oleh pihak swasta maupun pemerintah untuk memenuhi kebutuhan transportasi umum yang semakin meningkat. Yang memberikan kontribusi paling besar dalam hal pencemaran udara adalah terminal, karena menjadi sentral dari segala aktifitas yang menggunakan jasa transportasi baik pengelola terminal, pedagang dan pemakai jasa. Pencemaran udara bersumber dari asap cerobong industri dan gas buangan dari kendaraan bermotor. Penggunaan kendaraan bermotor menimbulkan dampak negatif terhadap lingkungan, terutama gas buang dari hasil pembakaran bahan bakar yang tidak terurai atau terbakar dengan sempurna. Kontributor terbesar polusi adalah substansi, substansi yang dimaksud adalah sulfur oksida (SOx). Polusi udara telah memberikan keterkaitan negatif bagi kesehatan manusia secara umum. Dalam hal ini khususnya dampak yang diterima oleh para pedagang makanan yang berada di sekitar area terminal. Para pedagang ini terkena paparan polusi udara setiap harinya. Penulisan ini bertujuan untuk mengetahui dampak polusi udara terhadap kesehatan para pedagang.
\end{abstract}

Kata kunci : pencemaran udara, sulfur oksida (SOx), transportasi 


\section{Pendahuluan}

Bidang kegiatan yang memiliki peran bagi masyarakat Indonesia merupakan transportasi atau biasa disebut pengangkutan. Bagi masyarakat di Indonesia, transportasi memiliki peran yang penting, hal ini bisa disebabkan oleh beberapa kondisi, seperti secara geografis Indonesia merupakan negara kepulauan dan perairan. Untuk menjangkau wilayah Indonesia yang sebagian besar adalah perairan, transportasi bisa dilakukan dengan melalui darat, periaran dan udara.[1]

Pembangunan ekonomis dan non ekonomis merupakan hal yang membutuhkan peran transportasi. Meningkatkan pendapatan nasional, pengembangan industri secara nasional serta memberi kesempatan bagi masyarakat merupakan tujuan yang bersifat ekonomis. Sedangkan tujuan yang bersifat non ekonomis adalah mewujudkan pertahan dan keamanan serta meningkatkan integritas bangsa.[2]

Salah satu jasa layanan yang disediakan oleh pemerintah maupun adalah terminal, guna memenuhi kebutuhan transportasi umum yang semakin meningkat. Eksistensi sebuah terminal semakin tinggi guna memenuhi tingkat kebutuhan masyarakat yang tidak sama.[3]

Sebagai tempat perpindahan antar moda angkutan dalam hal melayani angkutan barang maupun manusia disediakan sebuah terminal. Keleluasan keluar masuk dari sasaran yang akan dipindahkan baik angkutan penumpang maupun barang adalah salah satu fasilitas yang disediakan oleh sebuah terminal. Selain berfungsi melayani angkutan penumpang, tetapi juga bagi pemerintah dan operator adalah salah satu fungsi terminal dan fasilitas pelayanan umum lainnya.[4] Maka dari itu tingkat pelayanan yang baik dapat turut berkontribusi dalam hal pergerakan perpindahan penduduk dan kedisiplinan dalam berlalu-lintas. Tetapi, selain itu juga dapat berperan sebagai instrumen pendukung bagi penambahan pendapatan asli daerah (PAD) ditinjau dalam segi bidang retribusi. Sehingga terminal dituntut untuk beroperasi dengan efektif untuk memenuhi kebutuhan tersebut. Moda angkutan jalan raya merupakan yang paling sering digunakan oleh lebih dari 75\% orang bepergian.[5] Sehingga yang memiliki peran penting dalam sistem perhubungan dalam kota maupun luar kota di Indonesia adalah terminal bus antar kota.

Sebagai sumber daya manusia, tenaga kerja membutuhkan kepedulian yang lebih dari sisi mpetensi, keamanan dalam bekerja maupun kondisi kesehatan kerjanya. Efek lebih lanjut yang bisa ditemui oleh para pekerja salah satunya ialah ancaman kemalangan seperti kecelakaan dan penurunan kesehatan yang ditimbulkan dari pekerjaan. Area tempat kerja yang terpapar oleh partikel abu, uap, gas dan beberapa lainnya yang berlangsung pada satu pihak, bisa saja akan merintangi daya produksi dan kesehatan bagi yang lain.[6] Pada tahun 2013 ILO (International Labour Organization) memperkirakan setiap tahunnya pekerja yang meninggal diakibatkan dari kecelakaan beban kerja sebanyak lebih dari 2,34 juta orang.[7] Sebagian besar dari nilai tersebut diperkirakan sebanyak kurang lebih 2,00 juta pekerja meninggal karena sakit yang ditimbulkan berkaitan dengan pekerjaan yang terpapar partikel abu, gas ataupun uap.

Para pekerja dibidang transportasi tersebut mewujudkan bagian dari sektor yang memiliki kedudukan yang penting dalam peningkatan ekonomi secara global. Pertumbuhan bidang transportasi mewujudkan perluasan ekonomi yang semakin maju dan meningkat.[8] Disisi lain bidang transportasi juga menjadi salah satu sektor yang berkontribusi dalam menyumbang dampak negatif terhadap lingkungan.

Efek buruk yang bisa dihasilkan adalah meningkatnya pencemaran udara diarea perkotaan, yang merupakan produk dari emisi gas buangan kendaraan bermotor. Berdasarkan asal pencemaran, yang menyumbangkan polusi yang ada di udara adalah dari asap buangan kendaraan bermotor.[9] , [10]

Ada beberapa hal yang memberikan pengaruh terhadap kinerja dari terminal, yaitu: [11]

1. Pelayanan dan manajemen : kapasitas ruangan, jumlah kendaraan yang dapat ditampung, sistem perparkiran, ketersediaan pusat informasi dan faktor infrastuktur.

2. Aksesibilitas : keleluasaan perpindahan angkutan penumpang maupun barang menuju lokasi terminal dan ketika berada dalam terminal.

3. Tingkat pelayanan jalan : situasi dan kondisi jalan yang berada didalam maupun berada diarea terminal

4. Keamanan lingkungan : keadaan area terminal terhadap aksi kejahatan/kriminalitas. 
5. Kenyamanan lingkungan : keadaan area terminal dari sisi kebisingan, polusi udara dan kebersihan lingkungan.

Pembahasan dalam penulisan ini adalah tingkat faktor kenyamanan terhadap lingkungan. Tujuan dari penulisan ini adalah seberapa besar efek yang akan diakibatkan oleh jumlah kendaraan bermotor, khususnya adalah moda angkutan bus. Lokasi pembahasan yang diambil adalah diterminal. Sedangkan yang menjadi obyek pembahasan dalam penulisan ini adalah pedagang makanan yang berjualan didalam area terminal. Hal ini dikarenakan para pedagang makanan yang sering terkena paparan dari polusi asap kendaraan dalam waktu lama.

\section{Metode}

Studi literatur adalah cara yang dipakai untuk menghimpun data-data atau sumber-sumber yang berhubungan dengan topik yang diangkat dalam suatu penelitian. Studi literatur bisa didapat dari berbagai sumber, jurnal, buku dokumentasi, internet dan pustaka. Studi literatur merupakan jenis dari penelitian yang dilakukan, dengan menggali dari referensi teori yang sesuai persoalan yang akan ditelaah. Dalam penulisan ini membahas dampak yang diterima oleh para pedagang makanan disekitar terminal akibat dari paparan polusi udara yang diterima setiap hari.

Data sekunder yang digunakan penulis dalam melakukan penelitian ini yaitu data yang diambil dari jurnal, buku wacana maupun internet. Dengan menggunakan alur analisis deskripsi, beberapa data yang telah dikumpulkan akan dianalisis. Pola analisis deskripsi adalah menjelaskan maupun menggambarkan informasi yang diperoleh kemudian dilanjutkan dengan ulasan, bukan hanya sekedar menjabarkan, tetapi juga menyampaikan interpretasi secukupnya.

\section{Hasil dan Pembahasan}

\section{(1) Aktivitas Kendaraan Bermotor Yang Setiap Hari Memicu Adanya Pencemaran Udara}

Permasalahan lingkungan yang menyangkut keselamatan, kesehatan, dan kehidupan manusia membutuhkan perhatian lebih agar dapat diselesaikan. Aspek penting dan paling utama dalam aktivitas kehidupan adalah udara.[12] Kualitas udara menunjukkan perubahan seiring dengan semakin berkembangnya pusat-pusat industri dan perubahan fisik kota. Manusia ditakdirkan menghirup udara yang telah ada tanpa bisa menolak ataupun memilih. Pada saat terpapar zat-zat (dalam wujud gas ataupun partikel kceil atau aerosol) ke dalam udara hingga terjadi kontaminasi, maka bisa dipastikan manusia akan mendapatkan efek yang disebabkan oleh polusi tersebut.

Yang memberikan kontribusi paling besar dalam hal pencemaran udara adalah terminal, karena menjadi sentral dari segala aktifitas yang menggunakan jasa transportasi baik pengelola terminal, pedagang dan pemakai jasa.[13] Hampir dalam waktu 24 jam setiap harinya terdapat kegiatan kendaraan bermotor yang bisa menimbulkan adanya polusi udara disekitar area terminal.

Pembakaran bahan bakar yang megandung atom karbon yang tidak sempurna secara fisik tidak berwarna ataupun berbau dapat menghasilkan gas CO. Gejala ringan yang ditimbulkan akibat dari keracunan gas karbonmonoksida seperti kepala terasa pusing, mata terasa tidak nyaman atau perih, dan rasa mual ingin muntah. Untuk tingkat lebih lanjut, gejala yang dirasakan akan semakin berat seperti contohnya adalah berupa peningkatan kerja detak jantung, dada terasa tertekan, kesulitan dalam bernafas (sesak), otot-otot terasa melemah, sistem kardiovaskuler yang mulai terganggu, timbulnya serangan jantung hingga menyebabkan pada kematian. [14]

Karakteristik yang dimiliki dari gas $\mathrm{SO}_{2}$ adalah adanya aroma yang menyengat dan sulit terbakar di udara. Udara yang mengandung gas $\mathrm{SO}_{2}$ dapat menimbulkan iritasi saluran pernapasan dan kenaikan sekresi mukosa. Bahkan kematian pada manusia bisa disebabkan oleh gas $\mathrm{SO}_{2}$ yang telah mencapai konsentrasi 500 ppm.[15], [16]

Risiko kesehatan lingkungan terbesar di dunia disumbangkan oleh polusi udara. Pada tahun 2012, berdasarkan asumsi data menyimpulkan sebanyak sekitar kurang lebih 7 juta orang kehilangan nyawa setiap tahunnya dikarenakan terkontaminasi oleh pecemaran udara. Pada tahun 2008 angka kematian manusia tersebut naik sebanyak dua kali lipat. Yang lebih mengejutkan lagi adalah fakta dimana sebanyak $90 \%$ manusia yang hidup di negara-negara yang memiliki tingkat membahayakan 
pencemaran udaranya. Data yang telah diterbitkan mengenai kualitas udara tersebut telah sangat mencemaskan. Nilai tersebut berdasarkan dari hasil pengamatan perubahan kenaikan pencemaran udara di 1600 kota dalam 91 negara. World Health Organization (WHO) menetapkan bahwa hanya sekitar $12 \%$ warga yang ada didunia yang memiliki tempat tinggal dikota yang masuk kriteria memiliki syarat kelayakan jualitas udara. [17]

Batas kadar masing-masing pencemar udara telah ditetapkan oeleh pemerintah, melalui Peraturan Pemerintah No.41 Tahun 1999 tentang Pengendalian Pencemaran Udara. Standar nilai baku mutu udara nasional yang diijinkan adalah $\mathrm{SO}_{2}$ sebayak $900 \mathrm{ug} / \mathrm{Nm} 3$ dan untuk $\mathrm{CO}$ sebanyak 30.000 ug/Nm3. Standar mutu baku udara nasional adalah dihitung per 1 jam untuk setiap mutu baku.[18]

Dalam Sistem Periodik Unsur Kimia, Timbal $(\mathrm{Pb})$ tergolong masuk kedalam kelompok logam berat golongan IVA. Unsur tersebut memiliki penomoran atom 82 dengan berat atom 207,2 dan pada suhu kamar kan berbentuk padat. Yang memiliki titik lebur $327,4^{\circ} \mathrm{C}$ dan memiliki berat jenis sebesar 11,4/l. Pada kondisi keadaan bebas, $\mathrm{Pb}$ jarang ditemukan di alam tetapi dalam bentuk senyawa dengan molekul lain, seperti misalnya dalam bentuk $\mathrm{PbBr}_{2}$ dan $\mathrm{PbCl}_{2}$. Selain itu juga banyak juga digunakan sebagai bahan pengemas, untuk saluran air, peralatan rumah tangga dan hiasan. Industri kosmetik menggunakan oksida timbal sebagai pigmen/zat warna. Selain itu juga digunakan dalam industri keramik, Glace maupun dalam industri peralatan rumah tangga. Ketika berbentuk aerosol anorganik bisa masuk ke tubuh, dengan cara menghirup udara atau mengkonsumsi sayuran atau buah-buahan yang telah tercemar.

Logam $\mathrm{Pb}$ tersebut lama kelamaan akan menumpuk di dalam tubuh karena proses penghilangannya atau penetralisir yang membutuhkan waktu lama. Dalam satu liter bensin dalam memiliki angka oktan 87 dan 98 artinya mengandung $0,70 \mathrm{~g}$ senyawa $\mathrm{Pb}$ Tetraetil dan $0,84 \mathrm{~g}$ Tetrametil $\mathrm{Pb}$. Apabila dikonversikan maka untuk setiap liter bensin yang telah dibakar tersebut menyumbang emisi sebesar 0,56 $\mathrm{Pb}$ yang dikeluarkan secara bebas di udara.[19]

\section{(2) Dampak Polusi Udara Terhadap Kesehatan}

Tabel 1. Efek dari gas $\mathrm{SO}_{2}$ berdasarkan Depkes RI 2007

\begin{tabular}{cc}
\hline $\begin{array}{c}\text { Konsentrasi } \\
(\mathbf{p p m})\end{array}$ & Efek / pengaruh \\
\hline $3-5$ & Nilai terkecil yang dapat dideteksi dari baunya (selama 4 jam ) \\
$8-12$ & Nilai terkecil yang bisa menimbulkan radang tenggorokan (selama 4 jam) \\
20 & Nilai terkecil yang bisa menimbulkan iritasi pada mata (selama 4 jam ) \\
20 & Nilai terkecil yang akan menimbulkan batuk (selama 4 jam) \\
20 & Nilai maksimum yang diijinkan untuk konsentrasi (selama 4 jam) \\
$50-100$ & Nilai maksimum yang diijinkan untuk kontak dalam wktu singkat (30 menit) \\
$400-500$ & Berbahaya walaupun kontak secara singkat \\
\hline
\end{tabular}

Sumber: Depkes RI 2007

Pada tahun 2010 , Kementerian Lingkungan Hidup (KLH) mengeluarkan data bahwa pencemaran di udara dari kendaraan berbahan bakar bensin melebihi ambang batas yang telah ditetapkan akan memberikan kontribusi sebesar 70\% karbon monoksida (CO), 100\% Plumbum ( $\mathrm{Pb})$, $60 \%$ hidro karbon (HC) dan 60\% oksida nitrogen (NOX). Bahan yang bisa menyebabkan polusi seperti Karbon monoksida, Ozon (O3) dan $\mathrm{Pb}$ juga ditemukan pada daerah yang tinggi kepadatan lalu lintasnya.[20]

\section{(3) Bahaya Timbal (Pb)}

Setiap $1 \mathrm{~km}$ dari pembakaran bahan bakar bensin akan menyumbang emisi sebesar 0,09 gram. $\mathrm{Hal}$ ini yang mengakibatkan mengapa logam $\mathrm{Pb}$ yang terdapat di dalam bensin ini benar-benar rawan dan mengkhawatirkan. Sebagai contoh ibukota Jakarta, sebanyak kurang lebih 1 juta unit kendaraan 
bermotor yang melakukan pergerakan perpindahan sepanjang $15 \mathrm{~km}$ per hari akan menyumbangkan emisi sebesar 1,35 ton $\mathrm{Pb} /$ hari. Dampak yang diakibatkan tidak bisa dipandang sebelah mata.. Keterbelakangan IQ dan kerusakan otak yang ditimbulkan merupakan salah satu dampak yang ditimbulkan dari emisi timbal ini. Ciri-ciri keracunan timbal pada orang dewasa yang terjadi biasanya adalah kepala terasa berputar, nafsu makan menurun, kepala terasa sakit, darah rendah, insomnia, lelah, lesu, dan kehilangan janin yang dikandung. Ukuran dan bentuk sel darah merah yang mengalami perubahan yang bisa menyebabkan hipertensi merupakan bahaya lain ditimbulkan akibat timbal.

\section{(4) Hasil}

Berdasarkan hasil penelitian, konsentrasi debu, COx, NOx, SOx di terminal merupakan faktor resiko yang mempunyai kemungkinan besar untuk dapat menimbulkan menurunnya kinerja paru. Variabel yang berpengaruh secara signifikan terhadap gangguan fungsi paru pedagang tetap terminal adalah riwayat memiliki penyakit bawaan sebelumnya dan usia.[21]

Mengkonsumsi udara yang memiliki kandungan emisi gas buang dalam jumlah besar akan memberikan dampak yang membahayakan bagi kesehatan manusia. Gas monoksida dan $\mathrm{NO}_{2}$ merupakan dua jenis gas buang kendaraan yang perlu mendapat perhatian dengan seksama. Karena kedua jenis gas tersebut bisa memacu reaksi pada tubuh manusia yang membahayakan kualitas kesehatan manusia. Bahkan pada keadaan yang lebih spesifik dapat menimbulkan hal yang lebih buruk seperti kematian.[22]

\section{Kesimpulan}

Bagi aktivitas kegiatan masyarakat Indonesia, transportasi atau pengangkutan merupakan bidang kegiatan yang memiliki peran lebih. Peningkatan pembangunan ekonomi saat ini menunjukkan pertumbuhan di sektor transportasi. Namun, sektor ini juga sebagai salah satu sektor yang dapat memberikan dampak negatif terhadap lingkungan. Salah satunya adalah semakin naiknya pencemaran udara di area lingkungan kota, sebagai produk emisi gas buangan kendaraan bermotor.

Yang memberikan kontribusi paling besar dalam hal pencemaran udara adalah terminal, karena menjadi sentral dari segala aktifitas yang menggunakan jasa transportasi baik pengelola terminal, pedagang dan pemakai jasa.

Konsentrasi debu, COx, NOx, SOx di terminal merupakan faktor resiko yang memiliki kemungkinan yang besar untuk dapat menimbulkan gangguan fungsi paru. Emisi yang terkandung ada gas buang rawan bagi kesehatan manusia, apabila dikonsumsi dalam jumlah melwati ambang batas. Gas $\mathrm{CO}$ dan $\mathrm{NO}_{2}$ merupakan dua jenis gas buang kendaraan yang perlu mendapat perhatian dengan seksama. Karena kedua jenis gas tersebut bisa memacu reaksi pada tubuh manusia yang membahayakan kualitas kesehatan manusia. Bahkan pada keadaan yang lebih spesifik dapat menimbulkan hal yang lebih buruk seperti kematian.

\section{Referensi}

[1] M. Kadarisman, Y. Yuliantini, and S. A. Majid, "Formulasi Kebijakan Sistem Transportasi Laut," J. Manaj. Transp. Dan Logistik, vol. 3, no. 2, p. 161, 2017, doi: 10.25292/j.mtl.v3i2.101.

[2] D. L. A. W. Journal et al., "Diponegoro law journal," vol. 6, no. 22, pp. 1-13, 2017.

[3] A. A. Putra, "Analisis Keseimbangan Jumlah Armada Angkutan Umum Berdasarkan Kebutuhan Penumpang," Media Komun. Tek. Sipil, vol. 19, no. 1, pp. 1-12, 2014, doi: 10.14710/mkts.v19i1.7829.

[4] G. Lansart, M. R.E.Manopo, and F. Jansen, "Perencanaan Terminal Sasaran Sebagao Pengembangan Terminal Tonando Di Kabupaten Minahasa," J. Si ill Statik, vol. 3, no. 7, p. 476, 2015, [Online]. Available: https://media.neliti.com/media/publications/139960-ID-perencanaan-terminal-sasaran-sebagai-pen.pdf.

[5] T. Apriyanto, "Kerangka Evaluasi Pengembangan," J. Tek. Sipil Perenc., vol. Volume 10, pp. 85-92, 2008.

[6] P. Penggilingan, D. Batu, P. Di, P. T. Sinar, and U. Karya, “3164-Article Text-6222-1-10-20140413,” vol. 3, no. 1, pp. 1-9, 2014.

[7] D. Armbruster, Accuracy Controls, vol. 33, no. 1. 2013.

[8] H. A. Silondae, Sutami; Azis and Muthalib; Ernawati, "Keterkaitan Jalur Transportasi dan Interaksi 
Ekonomi Kabupaten Konawe Utara dengan Kabupaten Kota Sekitarnya,” J. Prog. Ekon. Pembang., vol. 1, no. 1, pp. 49-64, 2016.

[9] F. Jansen, S. L. Sengkey, and Steenie Wallah, "Tingkat Pencemaran Udara CO Akibat Lalu Lintas Dengan Model Prediksi Polusi Udara Skala Mikro,” J. Ilm. MEDIA Eng., vol. 1, no. 2, pp. 119-126, 2011, [Online]. Available: www.jurnal.lapan.go.id/index.php/berita_dirgantara/article/viewFile/687/605.

[10] Ismiyati, D. Marlita, and D. Saidah, "Pencemaran Udara Akibat Emisi Gas Buang Kendaraan Bermotor," J. Manaj. Transp. Logistik, vol. 01, no. 03, pp. 241-248, 2014.

[11] B. U. S. Majors and I. N. Surakarta, "Headway 3," vol. 10, no. 2, pp. 192-200, 2009.

[12] R. Ratnani, "Teknik Pengendalian Pencemaran Udara Yang Diakibatkan Oleh Partikel," J. Momentum UNWAHAS, vol. 4, no. 2, p. 114195, 2008.

[13] E. N. Sari, "Gambaran Kualitas Udara Ambien Terminal Kaitannya dengan Gangguan Fungsi Paru Pedagang Tetap Wanita di Terminal Joyoboyo Surabaya,” Indones. J. Occup. Saf. Heal., vol. 2, pp. 9095, 2013, [Online]. Available: http://journal.unair.ac.id/K3@gambaran-kualitas-udara-ambien-terminalkaitannya-dengan-gangguan-fungsi-paru-pedagang-tetap-wanita-di-terminal-joyoboyo-surabaya-article6722-media-39-category-3.html.

[14] Christyana Sandra, "Pengaruh penurunan kualitas udara terhadap fungsi paru dan keluhan pernafasan pada polisi lalu lintas polwiltabes surabaya," J. IKESMA, vol. 9, pp. 1-8, 2013.

[15] W. M. Report, M. Health, N. Understanding, N. Hope, and W. H. Day, “原著 12 2,*,” vol. 32, no. 2, pp. 140-154, 2013.

[16] H. Antara, T. Konsentrasi, S. O. D. A. N. Pm, R. Widowati, and B. Haryanto, "Di Udara Ambient Dengan Kejadian Ispa Penduduk Kecamatan Taman Sari Jakarta Barat 2006-2013 the Association Between Level Concentration of No 2, So 2 and Pm 10 in Ambient With Ari Occurrence At Resident in Taman Sari District West Jakarta in 2006-2013," vol. 10, no. 2, pp. 1-18, 2013.

[17] “Ambient (outdoor) air pollution,” Who. 2018, [Online]. Available: https://www.who.int/news-room/factsheets/detail/ambient-(outdoor)-air-quality-and-health.

[18] PP, "Presiden republik indonesia," Peratur. Pemerintah no. 41 tentang Pengendali. Pencemaran Udar., no. 1, pp. 1-5, 1999, doi: 10.1016/j.aquaculture.2007.03.021.

[19] D. Gusnita, "Pencemaran logam berat timbal (pb) di udara dan upaya penghapusan bensin bertimbal," Ber. Dirgant., vol. 13, no. 3, pp. 95-101, 2012.

[20] T. EMS, "Mengatasi Data Hilang Dan Serangan Virus," no. 41, p. 144, 2009.

[21] "Pengaruh kualitas Udara ( Debu,COx, NOx, SOx) Terminal Terhadap Gangguan Fungsi Paru Pada Pedagang Tetap Terminal Bus Induk Jawa Tengah, 2002," Jurnal Kesehatan Lingkungan Indonesia, vol. 2, no. 1. pp. 27-31, 2015, doi: 10.14710/jkli.2.1.27-31.

[22] D. Muziansyah, R. Sulistyorini, and S. Sebayang, "Model Emisi Gas Buangan Kendaraan Bermotor Akibat Aktivitas Transportasi ( Studi Kasus : Terminal Pasar Bawah Ramayana Koita Bandar Lampung )," Jrsdd, vol. 3, no. 1, pp. 57-70, 2015. 